Bangladesh J. Plant Taxon. 28(2): 451-453, 2021 (December)

- Short communication

(C) 2021 Bangladesh Association of Plant Taxonomists

DOI: https://doi.org/10.3329/bjpt.v28i2.57140

\title{
EXTREME EARLY-AGE FLOWERING OF A TALI PALM (CORYPHA TALIERA ROXB.) TREE
}

\author{
MD. Abul Hassan \\ Department of Botany, University of Dhaka, Dhaka-1000, Bangladesh
}

Keywords: Tali palm; Corypha taliera Roxb.; Early-age flowering; Bangladesh.

Tali palm, Corypha taliera Roxb. (Arecaceae) is a giant monocarpic plam discovered in 1919 in Bengal by William Roxburgh. The plant is regarded as endemic to Bengal (Siddiqui et al. 2007). Tali palm is a tall straight tree, attaining about 40-50 feet high and flowers usually after 6070 years. After flowering and fruiting the palm dies.

In Bangladesh, Tali palm was represented by a single individual which was first recognized in early 1950s in a scrub jungle between Jagannath Hall and Isa Khan staff quarters of the University of Dhaka. This plant was regarded as the only wild individual of Tali palm in the world (Khan et al. 2001a, b).

At the age of about 60 years or more the Dhaka Tali palm flowered during 2008-2009. Panicle initiation was first noticed on the 18th September 2008. The plant took a total of 431 days from panicle initiation to fruit ripening. From the initiation of fruits about 415 days were taken to ripe. The seeds took 30-48 days to germinate (Khondker et al., 2010).

As the plant was the only living individual in the world, after the plant had died producing hundreds of ripe fruits, initiatives were taken to raise seedlings from the seeds and to spread these to different areas to save from extinction of so called extinct palm. A large number of seedlings were raised from the seeds by the Department of Botany, University of Dhaka, by the Arboriculture section (University of Dhaka) and by Akhteruzzaman Chowdhury who was working on the Tali palm materials at the Department of Pharmaceutical Chemistry, University of Dhaka.

Seedlings of c. two years old were then planted in different suitable places. Chowdhury took a crash programme to spread the extinct Tali palm throughout the country and planted seedlings in different institutions, forest lands, Government offices including Circuit House Premise of Tangail district. He planted the seedlings in Tangail Circuit House Premise on $17^{\text {th }}$ June 2012.

In 2021, after only 9 years of plantation, one plant in the Circuit House Premise started flowering in very extreme early-age of eleven only (Fig. 1).

The plant is taxonomically very important but economically less important. However, hard trunk of Tali palm may be used for constructing houses, petioles as firewood and the leaf-blade as thatching materials (Siddiqui et al., 2007). Tali palm may become a candidate for a potential medicinal plant, because its young fruits have strong antioxidant activity $\left(\mathrm{LC}_{50} 19.33 \mu \mathrm{g} / \mathrm{ml}\right.$ as compared to $9.5 \mu \mathrm{g} / \mathrm{ml}$ for the standard BHT). It also exhibits antimicrobial activity against few pathogenic bacteria. The methanol extract revealed the strong cytotoxicity $\left(\left(\mathrm{IC}_{50}=0.43 \mu \mathrm{g} / \mathrm{ml}\right)\right.$ (Chowdhury et al., 2010). Crude methanolic extract of the fruits contains stigmasterol, $\beta$ sitosterol, $\beta$-amyrin, lupeol and betulinic acid which is reduced from betulin (Chowdhury et al., 2013). Betulin, a triterpene present in the fruits, inhibits the maturation of sterol regulatory element-binding protein which in turn, reduces the biosynthesis of cholesterol and fatty acids, improves hyperlipidemia and insulin resistance and reduces atherosclerotic plaques (Khan et al., 2017). 


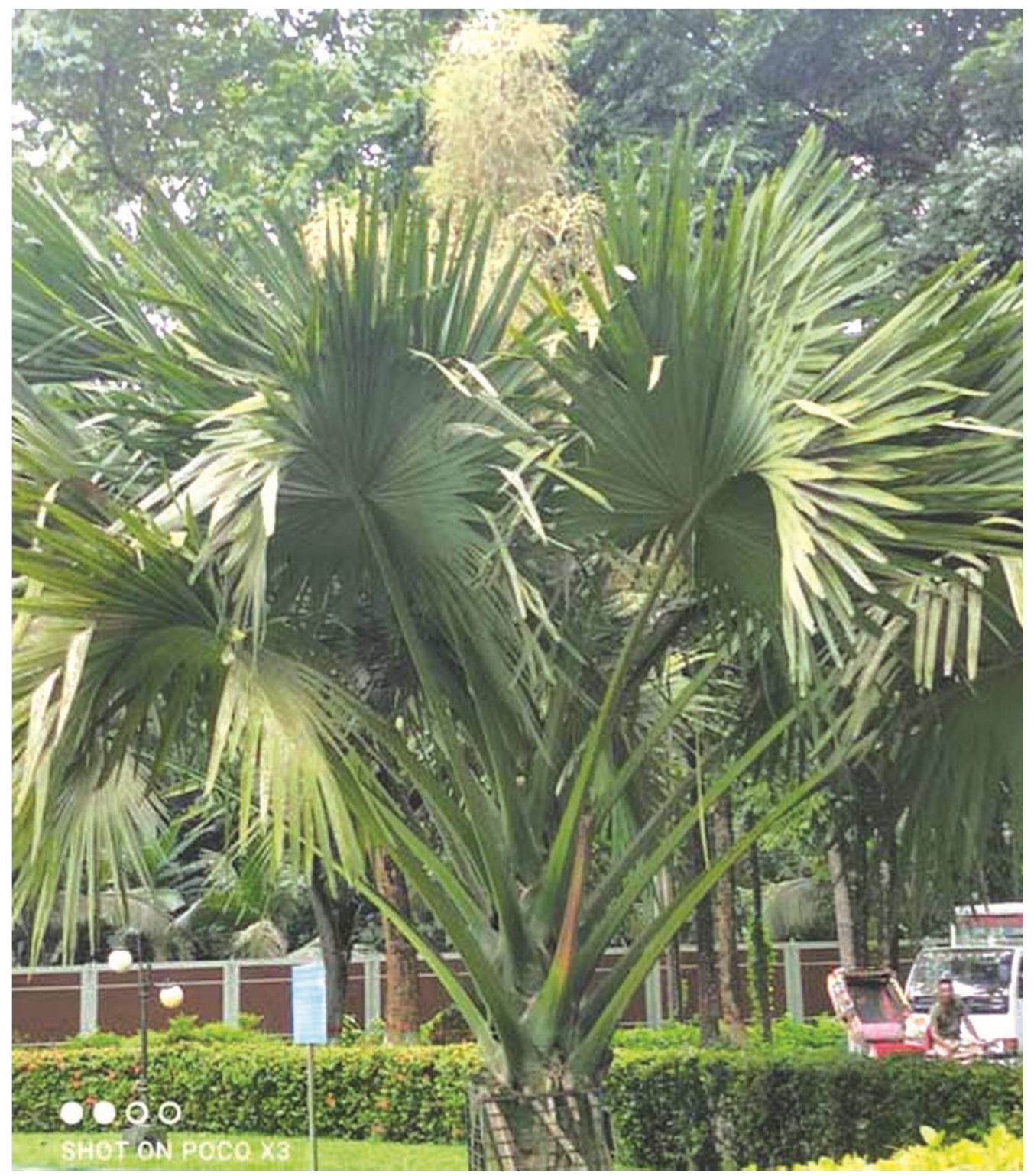

Fig. 1. An eleven year old Tali palm (Corypha taliera) with a panicle at the top.

Fresh flowers of Tali palm contain carbohydrate $41.62 \%$, protein $12.78 \%$, fat $1.25 \%$, calcium $256.51 \mathrm{mg}$, phosphorus $190.0 \mathrm{mg}$ and iron $36.80 \mathrm{mg}$. Pericarp and testa also contain high percentage of carbohydrate $(67.03 \%)$, protein $(14.70 \%)$, calcium $(240.0 \mathrm{mg})$, phosphorus $(212.0$ $\mathrm{mg}$ ) and iron (17.0 mg) (Khondker et al., 2010).

The medicinal and nutritional importance of Tali palm is directly related to its flowering and fruiting. Early flowering and fruiting of Tali palm may bring opportunity for further pharmaceutical research. It may also save the plant from extinction. The extreme early-age 
flowering might be due to environmental change or molecular level change which needs further detailed investigation.

\section{References}

Chowdhury, A., Alam, M.A., Rahman, M.S., Hassan, M.A. and Rashid, M.A. 2010. Antioxidant, antimicrobial and cytotoxic activity of Corypha taliera Roxb. Lat. Am. J. Pharm. 29(7): 1231-1234.

Chowdhury, A., Alam, M.A., Rashid, R.B., Al-Mansur, M.A., Rahman, M.S. and Rashid, M.A. 2013. Steroids and triterpenoids from Corypha taliera Roxb.: A critically endangered palm species of Bangladesh. Res. J. Med. Plant 7: 125-129.

Khan, M.S., Hassan, M.A. and Basu, S.K. 2001a. Rescue of an extinct palm in Bangladesh. Species 36: 9. Newsletter of the Species Survival Commission, IUCN-World Conservation Union.

Khan, M.S., Rahman, M. and Ali, M.A. (Eds). 2001b. Red Data Book of Vascular Plants of Bangladesh. Bangladesh National Herbarium, Dhaka, 179 pp.

Khan, M.F., Rashid, R.B., Hossain, M.A. and Rashid, M.A. 2017. Computational study of solvent free energy, dipole moment, polarizability, hyperpolarizability and molecular properties of betulin, a constituent of Corypha taliera Roxb. Dhaka Univ. J. Pharm. Sci. 16(1): 1-8.

Khondker, M., Hassan, M.A., Alfasane, M.A. and Shahjadee, U.F. 2010. Flowering and fruiting characteristics and biochemical composition of an endemic palm species (Corypha taliera Roxb.). Bangladesh J. Plant Taxon. 17(1): 79-86.

Siddiqui, K.U., Islam, M.A., Ahmed, Z.U., Begum, Z.N.T., Hassan, M.A., Khondker, M., Rahman, M.M., Kabir, S.M.H., Ahmed, M., Ahmed, A.T.A., Rahman, A.K.A. and Haque, E.U. (Eds). 2007. Encyclopedia of Flora and Fauna of Bangladesh, Vol. 11. Angiosperms: Monocotyledons (Agavaceae Najadaceae), Asiatic Society of Bangladesh, Dhaka, 399 pp.

(Manuscript received on 5 July 2021; revised on 8 December 2021) 